\title{
EFFECTS OF EXERCISE ON APPETITE AND FOOD INTAKE REGULATION
}

\author{
Jan Bilski 1 (ABDEF), Aneta Teległów ${ }^{2(\mathrm{ABEF})}$, Janina Zahradnik-Bilska ${ }^{3(\mathrm{ABDE})}$, Artur Dembiński ${ }^{4(\mathrm{ABF})}$, Zygmunt \\ Warzecha $^{4(\mathrm{ABF})}$ \\ ${ }^{1}$ Department of Ergonomics and Exercise Physiology, Jagiellonian University Medical College, Cracow, \\ Poland \\ ${ }^{2}$ Department of Clinical Rehabilitation, University School of Physical Education, Cracow, Poland \\ ${ }^{3}$ Department of Gastroenterology, Hepatology and Infectious Diseases, Jagiellonian University Medical \\ College, Cracow, Poland \\ ${ }^{4}$ Department of Physiology, Jagiellonian University Medical College, Cracow, Poland
}

\begin{abstract}
In this review, we discuss the effects of acute and chronic exercise on appetite and food intake regulation, the potential mechanisms involved and its relationship with hormonal and metabolic changes that affect energy balance. The mechanisms of post exercise short-term appetite modification remain unclear and although the role of orexigenic and anorexigenic peptides is possible hypotheses, it still remains unproven. Motivation to eat and food intake in response to acute exercise seem to be modulated by gender, body weight and eating behavior. In general, acute exercise has no effect on subsequent El in men, whereas in women an increase in El is usually observed, either decreasing or abolishing the effects of exercise on EB. Normal weight women, unlike men, report an increased palatability of foods with exercise and do not experience the transient suppression of hunger observed immediately after exercise. The evidence to date emphasizes the need to increase physical exercise levels, particularly because of the high prevalence of obesity. More research is needed to explain the mechanisms behind the post exercise adjustments in short-term appetite control, and their long-term consequences.
\end{abstract}

Key words: appetite, energy intake, exercise, leptin, ghrelin

\section{Introduction}

Body weight is regulated by a balance between food intake and energy expenditure and exercise is an effective method of increasing the latter. In human organism exists complex physiological system which balances energy intake (EI) and energy expenditure (EE) consisting of afferent signals, integrated by peripheral nerves and brain centers (1). However, evolutionary pressure has resulted in a drive to eat when food is available and in a shift in diet towards increased intake of energy-dense foods. This situation is also associated with a decrease in the quantity and intensity of physical activity (PA), caused by dramatic changes in lifestyle (2). The object of this article is to review the role of physical activity in influencing food intake.

\section{Food intake control - an overview}

Feeding behavior is a complex interaction of various processes controlling the initiation and termination of meal, its size, composition and frequency, and the long-term regulation of food intake in relation to body energy requirements. Food intake behavior in general and appetite in particular depends also on various aspects of eating patterns such as energy density of foods consumed, variety of foods accepted and palatability of the diet. It is associated with sensory aspects of food (sight, taste and smell), emotional cues, social situations, and cultural conventions. Sensory information interacts with internal physiologic signals that relate the nutrient and energy status of the body to determine the time, size, and composition of a meal. This information is integrated in the central nervous system, predominantly in the hypothalamus $(3,4)$. Physiological signals generated by the sight, smell and even idea of meal represent the cephalic phase of appetite. Gastric and intestinal signals also provide important information on the quantity and composition of the ingested nutrients. Afferent information from the mouth provides primarily positive and that from the stomach and intestine primarily negative feedback for eating. In addition, the intraluminal food and digestion products initiate the secretion of a plethora of hormones and peptides $(5,6)$.

\section{A central control of food intake}

It is well established that the hypothalamic region of the brain plays a key role in the central regulation of eating behavior in humans and a role for the ventromedial nucleus as a 'satiety centre' and the lateral hypothalamic nucleus (LHA) as a 'hunger centre' was 
suggested. However, food intake behavior is now thought to be regulated by neuronal circuits, which signal using specific neuropeptides (7). In particular, the arcuate nucleus (ARC) plays an essential role in the integration of signals regulating appetite with two populations of neurons. One neuronal circuit inhibits food intake, via the expression of the neuropeptides pro-opiomelanocortin (POMC) and cocaine- and amphetamine-regulated transcript (CART and the other stimulates food intake, via the expression of neuropeptide Y (NPY) and agouti-related peptide (AgRP). From the arcuate nucleus, these neurons project to second-order, melanocortin 4 receptor (MC4R) expressing neurons in brain areas that are involved in energy homeostasis such as the paraventricular nucleus (PVN), LHA, and dorsomedial hypothalamus (DMN). After feeding, augmented leptin concentration stimulates POMC neurons, increasing melanocortin levels while inhibiting AgRP neurons. This in turn stimulates signaling at MC4R, decreasing food intake and increasing energy expenditure. During fasting, a decrease in leptin inactivates POMC neurons (reducing melanocortin levels) and stimulates AgRP expression. The resultant decrease in MC4R signaling stimulates feeding and reduces energy expenditure (7). NPY is the most potent stimulator of feeding known with a key site of action in the paraventricular nucleus $(\mathrm{PVN})$ of the hypothalamus (8-10). CART is co-expressed with $\alpha-\mathrm{MSH}$ in the ARC. Melanocortins, including adrenocorticotrophin and melanocyte-stimulating hormones (MSHs), are peptide-cleavage products of the POMC molecule and exert their effects by binding to the melanocortin receptor family (10). The caudal brainstem nucleus of the solitary tract (NTS) is the initial central nervous system (CNS) terminus for a variety of gastrointestinal mechanical, nutrient chemical and gut peptide signals that limit the amount of food consumed during a meal. It receives projections from gut vagal and non-vagal visceral afferents and reciprocally connects to a range of hypothalamic and limbic system sites that play significant roles in the neural processing of meal-related stimuli and in determining food consumption $(11,12)$.

The motivational state is a product of limbic influences relayed by the amygdala, and reward factors. Amygdala is one of critical centers to regulate weight and ingestive behavior. Robust increases in body weight and food intake has been observed in rats with lesions of the basolateral amygdala (BLA) and postorodorsal amygdala (PDA). Adding reward experience to food is a way of avoiding foods with taste indicating the presence of noxious substances, and promoting those which taste signals particular nutritional value. As a result, coupling feeding with pleasure may override normal satiety mechanisms, resulting in hyperphagia and obesity. The sensation of reward is, however, influenced by energy status. Thus, signals of energy status, such as leptin, are able to influence the reward pathways (13). The reward circuitry is complex and involves interactions between several signaling systems. Opioids play an important role, as a lack of either enkephalin or $\beta$-endorphin in mice abolishes the reinforcing property of food, regardless of the palatability of the food tested. In man, opiate antagonists are found to reduce food palatability without reducing subjective hunger $(14,15)$. The endocannabinoid system regulates food intake via central and peripheral mechanisms and may be involved in the motivation to find and eat rewarding foods. Within the hypothalamus, endocannabinoids may influence food intake by regulating expression and/or action of anorectic and orexigenic mediators in the PVN, LH, and VMN. Levels of endogenous cannabinoids are increased within the duodenum with fasting and may act via the vagus and brainstem to reduce feelings of satiety $(16,17)$.

\section{Peripheral control of food intake}

A number of circulating substances can have an important influence on food intake behavior through their actions on the hypothalamus, the brain stem, or afferent autonomic nerves. They come from at least three sites: adipose tissue, the gastrointestinal tract and the endocrine pancreas.

\section{Peripheral signals from adipose tissue}

It is now obvious that adipose tissue is not mere storage depot of excess energy but an endocrine organ which plays a prominent role in regulation of satiety, carbohydrate and lipid metabolism, and insulin sensitivity. In addition to leptin, other cytokines including tumor necrosis factor (TNF)- $\alpha$, interleukin-6 (IL-6), resistin, visfatin, acylation stimulation protein, and adiponectin have been identified as adipose-secreted proteins that are collectively referred to as adipocytokines (18).

Leptin influences energy homeostasis, immune and neuroendocrine functions acting in the CNS through a class 1 cytokine receptor. Leptin inhibits NPY/AgRP neurons, and fasting significantly upregulates the expression of NPY and AgRP. In contrast, POMC/CART neurons are stimulated by leptin and fasting decreases POMC expression. Although its action within the hypothalamus is critical to its anorexigenic effects, there are other sites important for leptin action, including the vagal afferents, caudal brainstem and the ventral tegmental area. Acting upon dopaminergic neurons in this latter region, leptin also influences the reward and motivational aspects of ingestive behavior (19).

Adiponectin is an abundantly expressed adipokine in adipose tissue and has direct insulin sensitizing activity. In addition, adiponectin enhances AMP-acti- 
vated protein kinase activity in the arcuate hypothalamus via its receptor AdipoR1 to stimulate food intake and decreases energy expenditure (20). Visfatin is a recently discovered adipokine, which is highly expressed in visceral fat. Adipocyte visfatin expression and plasma concentrations increase with obesity in animals and humans and it exhibits an insulin mimetic effect. Intracerebroventricular injection of visfatin caused orexigenic effects in chicks (21).

\section{Peripheral signals from the gastrointestinal tract and the endocrine pancreas}

Insulin has a major and unique role in controlling the disposition of nutrients in the periphery. Insulin receptors are widely distributed within the brain and are found within the ARC on POMC neurons. Insulin has a potent appetite-suppressive effect when given centrally, although it is unlikely that this is mediated via POMC neurons $(22,23)$. Leptin and insulin could regulate the body weight not only directly, but also indirectly by modulating the sensitivity of the brain to satiety signals (24).

Ghrelin discovered as an endogenous ligand for the growth hormone secretagogue receptor (GHSR) is an orexigenic factor produced mainly by $\mathrm{P} / \mathrm{D} 1$ cells lining the fundus of the human stomach, but also in duodenum, ileum, caecum and colon. It has been proposed to be an enteric signal involved in energy homeostasis, being unique in that it stimulates appetite. An increase in circulating ghrelin levels may occur as a consequence of the anticipation of food, or may have a physiological role in initiating feeding. Ghrelin is thought to exert its orexigenic action via the ARC of the hypothalamus acting on neuropeptide NPY and AgRP. A new set of ghrelin-positive neurons within the hypothalamus, lying between the dorsal, ventral, paraventricular, and arcuate nuclei, were identified by immunohistochemistry (25). At least part of ghrelin and leptin signaling from the stomach is mediated by an ascending neural network through the vagus nerve and brainstem nuclei that ultimately reaches the hypothalamus. Ghrelin also may engage mesolimbic reward circuitry to increase the motivation to obtain food (26). Obestatin is encoded by the same gene as ghrelin and also present in stomach. Obestatin was reported to have opposite actions to ghrelin in the regulation of food intake, emptying of the stomach and body weight (27).

Pancreatic polypeptide (PP), peptide YY (PYY), and NPY share a similar structure known as the PPfold (28). PP from endocrine pancreas and PYY from the L-cells in distal gastrointestinal tract, particularly the ileum, colon and rectum are secreted in proportion to the energy intake. Their infusion decreased appetite, and caused a reduction in food intake. PP may also exert some anorectic action via the vagal pathway to the brainstem, as vagotomy seems to reduce its efficacy (6). In contrast, the central actions of PYY are orexigenic (29).

Main products generated from proglucagon are glucagon in the pancreas and oxyntomodulin (OXM), glucagon-like peptide-1 (GLP-1) and 2 (GLP-2) in the brain and intestine $(30,31)$. OXM is released from the gut postprandially, in proportion to energy intake, and circulating levels of OXM are elevated in several conditions associated with anorexia. Central injection of OXM reduces food intake and weight gain in rodents(32). Intravenous administration of GLP-1 in humans decreases food intake in a dose-dependent manner. Within the hypothalamus, GLP-1-containing nerve fibers and terminals have been shown to be located in the PVN, LHA and DMN, well known as integrative areas for feeding regulation. In addition, GLP-1 is also present in the amygdala, a brain region providing neuronal input to the hypothalamus and participating in the regulation of ingestive behavior (33).

Cholecystokinin (CCK) is released in the duodenum and jejunum, in response to fat- or protein-rich chyme entering the duodenum and is also found within the brain where it functions as a neurotransmitter involved in diverse processes such as reward behavior, memory and anxiety, as well as satiety. Administration of CCK has long been known to inhibit food intake by reducing meal size and duration. Peripheral CCK may act both on the vagal nerve and directly on the CNS by crossing the blood brain barrier (34). Orexins are produced in endocrine cells in the gut in addition to neurons in the LHA. A recent study localized the orexin-1 receptors on vagal afferent neurons that also expressed CCK-1 (A) and leptin receptors and showed that orexin inhibited the response of afferent nerve fibers to CCK (35).

\section{Exercise and food intake control Effects of exercise on motivation to eat and energy intake}

Physical activity was believed to be an unproductive form of weight control because of the assumed accompanying increase in food intake. Recently, some studies have shown however that acute exercise induces a short inhibition of appetite, even if this does not automatically translate into a decrease in following food intake (36-38). Interestingly, only 19\% of the intervention studies report an increase in energy intake after exercise, and 65\% show no change (39). Also when the physical activity level decreases, food intake does not seem to be down-regulated in the same way. These observations stressed the relatively weak coupling between energy intake and expenditure $(37,39-48)$. 


\section{Animal studies}

In rats forced exercise such as extensive treadmill running or strenuous swimming resulted in significant reductions in appetite, food intake, and body weight compared with sedentary animals (49-54). Lateral ventricular injection of a CRF antagonist prevented the effects of exercise on food intake and body weight suggesting a major role for CRF in the anorexia caused by exercise in male rats (55). However, lesions of either the paraventricular nucleus or the central nucleus of amygdala, where the main functional sites for brain CRF in food intake control have been identified (56), did not prevent the inhibitory effects of exercise on food intake and body weight $(57,58)$. It has been demonstrated that exercise increased the concentration of the NPY in multiple hypothalamic sites including the arcuate nucleus, the dorsomedial nuclei, the medial preoptic area, and the lateral hypothalamus (59). Contrary to forced exercise, voluntary exercise decreased food intake only in the short term (within the initial $1-2 \mathrm{wk}$ ), with a subsequent normalization or even increased intake in response to the energy demands of exercise $(60,61)$. Voluntary exercise in rats significantly decreased body weight and resulted in a significant elevation of CRF mRNA expression in the dorsomedial hypothalamus but not the paraventricular nucleus. Seven-day running wheel access also resulted in elevated arcuate nucleus and DMH NPY gene expression. Exercise-induced reductions of food intake and body weight were significantly attenuated by ventricular injection of the CRF antagonist and effect on food intake was specific to a blockade of activity-induced changes in meal size (62).

\section{Human studies}

Even though most human studies show no impact of acute exercise on appetite or subsequent EI this is rather controversial area. One reason that studies have not demonstrated changes in EI could be that they haven't follow EI for an adequately long time after the increased physical activity interventions, and that the exercised-induced rise in EE was not big enough to stimulate appetite. However, even with a high dose of exercise (gross exercise-induced increase in $\mathrm{EE}=4.6$ $\mathrm{MJ}$ ) in a single day and tracking EI for the following two days, there was no compensatory rise in hunger and EI (40). Most of the evidence implies that exerciseinduced changes in energy metabolism appear to have only a weak influence on eating behavior. In several human studies in spite of a lack of an effect on EI there was observed a considerable decrease in subjective hunger after intensive exercise. This exercise-induced anorexia was observed only during, and for a short time after intensive $\left(>60 \% \dot{\mathrm{V}}_{2} \max \right)$ exercise. This suppression of hunger is short lived and not seen with low-intensity exercise $(38,42,43,45,63)$. A redistribu- tion of blood flow from the splanchnic circulation, towards the skeletal muscles observed during exercise, could be implicated in this phenomenon (64). Rowell and colleagues found a $60-70 \%$ decrease in splanchnic blood flow in humans exercising at $70 \% \mathrm{VO}_{2} \max$ (65). At maximal exercise intensity, splanchnic blood flow may be reduced by about $80 \%$ (66). Some studies have shown uncoupling between subjective feelings of hunger and food intake. In these studies significant increase in EI at the buffet meal after moderate exercise was associated with no changes in subjective hunger. It was hypothesized that this phenomenon was the result of cognitive factors such as the belief that exercise increases hunger or the common behavior of using food as reward for exercising (67).

There is growing evidence that it takes considerable time for EI to adjust to elevations of EE. Lim \& Lee studied the impact of 5 months of basic military training on body weight, body fat and lean body mass in 197 males, classified as normal-weight, obese and very obese (68). Two key features of this study are that training was incremental; allowing subjects to gradually become fitter, and food intake was ad libitum. Over the 5 months of training fat-free mass did not change but subjects lost substantial amounts of weight and body fat. Subjects who were initially fatter lost more weight and more fat. This finding suggests that responses of EI to exercise-induced changes in EE may be different for lean and obese individuals.

Motivation to eat and food intake in response to acute exercise seem to be modulated by gender, body weight and eating behavior. Woo and colleagues (69-71) have carried out a series of three studies under metabolic balance conditions, ranging from 19 to 57 days in lean and overweight women and noticed a graded increase in EE due to exercise markedly elevated total daily $\mathrm{EE}$, which brought on a negative EB that was more or less proportional to the energy cost of exercise. These studies allowed comparing the responses of men and women to the similar graded-exercise intervention and a gender effect for EI and EE was observed. On average, men expended 13-8 MJ/d while women spent 10-7 $\mathrm{MJ} / \mathrm{d}$. There was observed a tendency for women to compensate through EI and the tendency for the men's EE to exceed the prescribed energy cost of exercise. In general, acute exercise has no effect on subsequent El in men, whereas in women an increase in EI is usually observed, either decreasing or abolishing the effects of exercise on EB $(45,72)$. Normal weight women, unlike men, report an increased sensory attractiveness of food with exercise and do not experience the transient suppression of hunger observed immediately after exercise $(41,42)$. Increasing exercise intensity in young women caused an increase in energy intake during the meal that follows the exercise session and the increase in energy intake on the day of the intervention was sufficient to 
almost totally compensate for the exercise-induced $\mathrm{EE}$ (73-76). This might contribute to the observation that exercise often fails to induce weight loss in women. It was postulated that light exercise could be better at favoring negative energy balance in young women and that intensive exercise could be better suited for men (41).

Obesity can also affect the response to exercise and while it has been shown that normal weight individuals (mainly women) increase their EI in response to a 3-day exercise intervention, compared with a similar period of rest, obese subjects fail to show such a compensatory response (77). Recently, Borer et al. have shown that after exercise appetite was suppressed in lean but not in obese women and suggested a role for leptin in this observation (78).

Swimmers have higher energy intakes than other athletes and eat more energy than they expend. Some research suggests that this is due to the cool temperatures in which swimmers train. By contrast, runners and cyclists usually experience an increase in body temperature during training, which may serve in the short term to suppress appetite. The classical "thermostatic” theory of food intake proposed as the method in which the additional heat produced in the body causes satiety (79) has got lately some molecular basis (80).

Although exercise is able to produce a negative EB in the short to medium term in the absence of dietary restrictions, long-term exercise only results in modest weight loss (81). This relative lack of efficacy in inducing weight loss does not mean that exercise has no benefits in obesity treatment. Regular exercise, even without weight loss is associated with a substantial reduction in total and visceral fat and with a significant improvement in fitness levels in obese individuals (82). There was argued that physically active persons have a better ability to control their food intake and energy balance because of increased appetite sensitivity. Recently, Long et al. (55) demonstrated that habitual exercisers have an increased accuracy of short-term regulation of food intake in compensation for high-carbohydrate preload. Insulin sensitivity has been proposed as one mechanism by which activity-induced improvements in appetite regulation occur. Exercise is known to increase insulin sensitivity (83), and insulin sensitivity is known to be involved in satiety induced by particular foods (84). Following a period of intensive exercise $\left(70 \% \mathrm{~V}_{2}\right.$ max for $50 \mathrm{~min}$ ), subjects were better able to discriminate between the energy values of so-called energy-rich and non-energy-rich beverages (85). Consequently, physical activity may improve the sensitivity of satiety signaling systems to consumed food. Physical activity could also modify macronutrient preferences and food choices; this response reflected in the food quotient of the diet selected following episodes of physical activity $(42,86)$. This effect could be identified via preferences for particular tastes associated with certain nutrients, e.g. sweetness, that would normally be associated with carbohydrate energy needed to replace the glycogen used in exercise (38). Physical exercise may influence appetite by modulating the hedonic response to foods, i.e. individuals would report greater pleasure from food consumption following a period of exercise. This phenomenon has been demonstrated for female dieters who showed increased ratings of pleasantness for a range of foods after exercise (87). These observations indicated that physical activity can improve the sensitivity of the appetite control system, adjust macronutrient preferences or food choices and enhance the pleasure derived from food consumption.

Table 1. Studies assessing the effects of exercise on hunger scores and energy intake

\begin{tabular}{|c|c|c|c|c|}
\hline Reference & Subjects & Intervention & Energy intake & Hunger scores \\
\hline $\begin{array}{l}\text { Thompson et } \\
\text { al. (45) }\end{array}$ & $\begin{array}{l}\text { Normal weight } \\
\text { college-age males }\end{array}$ & $\begin{array}{l}\text { Exercise at } 35 \% \text { and } 68 \% \\
\dot{\mathrm{VO}}_{2} \text { max (cycle ergometer) } \\
\text { versus resting }\end{array}$ & No significant effect & $\begin{array}{l}\text { Brief hunger scores } \\
\text { decrease }\end{array}$ \\
\hline $\begin{array}{l}\text { Kissileff et al. } \\
(63)\end{array}$ & $\begin{array}{l}\text { Obese and nine } \\
\text { nonobese women }\end{array}$ & $\begin{array}{l}\text { Exercised either strenu- } \\
\text { ously }(90 \mathrm{~W}) \text { or modera- } \\
\text { tely }(30 \mathrm{~W})(\text { cycle ergo- } \\
\text { meter) for } 40 \text { min versus } \\
\text { resting }\end{array}$ & $\begin{array}{l}\text { Intake of a liquefied test meal } \\
(1.04 \mathrm{kcal} / \mathrm{g}) 15 \text { min after } \\
\text { exercise was significantly } \\
\text { decreased after strenuous } \\
\text { exercise in the nonobese } \\
\text { women }\end{array}$ & Not tested \\
\hline $\begin{array}{l}\text { King et al. } \\
(40)\end{array}$ & $\begin{array}{l}\text { Lean males regular } \\
\text { exercisers }\end{array}$ & $\begin{array}{l}\text { Treadmill running at } \\
\text { approximately } 70 \% \text { max } \\
\text { heart rate for } 50 \mathrm{~min} .\end{array}$ & No significant effect & $\begin{array}{l}\text { Hunger scores } \\
\text { decrease }\end{array}$ \\
\hline $\begin{array}{l}\text { King et al. } \\
(42)\end{array}$ & Lean, healthy males & $\begin{array}{l}\text { Exercise session (at } 70 \% \\
\mathrm{~V}_{2} \max \text { (running or cyc- } \\
\text { ling) versus resting }\end{array}$ & $\begin{array}{l}\text { Delay to the onset of eating. } \\
\text { No significant effect on the } \\
\text { total amount of food eaten, } \\
\text { but high-fat/low-carbohydra- } \\
\text { te foods energy intake was } \\
\text { significantly elevated }\end{array}$ & $\begin{array}{l}\text { Transitory hunger } \\
\text { scores decrease }\end{array}$ \\
\hline
\end{tabular}




\begin{tabular}{|c|c|c|c|c|}
\hline Reference & Subjects & Intervention & Energy intake & Hunger scores \\
\hline $\begin{array}{l}\text { King et al. } \\
(41)\end{array}$ & $\begin{array}{l}\text { Dietary unrestra- } \\
\text { ined, normal weight } \\
\text { females }\end{array}$ & $\begin{array}{l}\text { Exercise at } 70 \% \dot{\mathrm{VO}}_{2} \max \\
\text { versus resting }\end{array}$ & No significant effect & $\begin{array}{l}\text { No significant } \\
\text { effect }\end{array}$ \\
\hline $\begin{array}{l}\text { Westerterp- } \\
\text { Plantenga et } \\
\text { al. (38) }\end{array}$ & $\begin{array}{l}\text { Normal weight } \\
\text { males }\end{array}$ & $\begin{array}{l}2 \mathrm{~h} \text { of cycling at } 60 \% \text { of } \\
\mathrm{V}_{2} \text { max versus resting }\end{array}$ & Energy intake decreased & $\begin{array}{l}\text { Hunger scores } \\
\text { decreased and } \\
\text { perception of } \\
\text { bitterness at a low } \\
\text { concentration } \\
\text { increased }\end{array}$ \\
\hline $\begin{array}{l}\text { Lluch et al. } \\
\text { (87) }\end{array}$ & $\begin{array}{l}\text { Dietary restrained } \\
\text { females, normal } \\
\text { weight and regular } \\
\text { exercisers }\end{array}$ & $\begin{array}{l}50 \text { min of cycling at } 70 \% \\
\dot{\mathrm{V}_{2}} \text { max versus resting }\end{array}$ & $\begin{array}{l}\text { No significant effect on total } \\
\text { energy intake but high-fat/ } \\
\text { low-fat foods energy intake } \\
\text { significantly elevated. }\end{array}$ & $\begin{array}{l}\text { No significant } \\
\text { effect on hunger } \\
\text { scores, exercise } \\
\text { raised the perce- } \\
\text { ived pleasantness } \\
\text { of foods }\end{array}$ \\
\hline $\begin{array}{l}\text { Imbeault et } \\
\text { al. }(72)\end{array}$ & $\begin{array}{l}\text { Young moderate- } \\
\text { ly active, normal } \\
\text { weight men }\end{array}$ & $\begin{array}{l}\text { Treadmill running at } \\
35 \% \dot{\mathrm{VO}}_{2} \text { max and } 75 \% \\
\dot{\mathrm{V}} \mathrm{O}_{2} \mathrm{max} \text { for a duration } \\
\text { allowing an exercise ener- } \\
\text { gy expenditure of about } \\
2050 \mathrm{~kJ}\end{array}$ & $\begin{array}{l}\text { No significant change in total } \\
\text { energy and macronutrient }\end{array}$ & $\begin{array}{l}\text { No significant } \\
\text { change in post- } \\
\text { exercise subjective } \\
\text { levels of hunger } \\
\text { and fullness }\end{array}$ \\
\hline $\begin{array}{l}\text { Pomerleau et } \\
\text { al (76) }\end{array}$ & $\begin{array}{l}\text { Moderately active } \\
\text { normal weight } \\
\text { females }\end{array}$ & $\begin{array}{l}\text { Low- and high-intensity } \\
\text { exercise sessions at } 40 \% \\
\text { and } 70 \% \text { of } \dot{\mathrm{V}}_{2} \text { max ver- } \\
\text { sus resting }\end{array}$ & $\begin{array}{l}\text { High-intensity exercise incre- } \\
\text { ases energy intake in women }\end{array}$ & $\begin{array}{l}\text { No significant } \\
\text { effect }\end{array}$ \\
\hline $\begin{array}{l}\text { Erdmann et } \\
\text { al. }(88)\end{array}$ & $\begin{array}{l}\text { Males and females } \\
\text { normal weight }\end{array}$ & $\begin{array}{l}\text { Group A cycling for } 30 \\
\text { min at } 50 \mathrm{~W} \text { and } 100 \text { and } \\
\text { group } \mathrm{B} \text { at } 50 \mathrm{~W} \text { for } 30,60 \\
\text { and } 120 \text { min versus resting }\end{array}$ & $\begin{array}{l}\text { Food intake after } 120 \text { min } \\
\text { of cycling was significantly } \\
\text { greater compared to control, } \\
30 \text { min and } 60 \text { min exercise }\end{array}$ & $\begin{array}{l}\text { No significant } \\
\text { effect }\end{array}$ \\
\hline $\begin{array}{l}\text { Martins et al. } \\
(67)\end{array}$ & $\begin{array}{l}\text { Normal-weight } \\
\text { volunteers (males } \\
\text { and females) }\end{array}$ & $\begin{array}{l}\text { Cycled for } 60 \mathrm{~min} \text { at } 65 \% \\
\text { of max hear rate or rested }\end{array}$ & $\begin{array}{l}\text { Exercise significantly incre- } \\
\text { ased subsequent absolute EI, } \\
\text { but produced a significant } \\
\text { decrease in relative EI after } \\
\text { accounting for the energy } \\
\text { expended during exercise }\end{array}$ & $\begin{array}{l}\text { During the exercise } \\
\text { period, hunger } \\
\text { scores were signi- } \\
\text { ficantly decreased; } \\
\text { however, this effect } \\
\text { disappeared in } \\
\text { the post-exercise } \\
\text { period }\end{array}$ \\
\hline $\begin{array}{l}\text { Dodd et al } \\
(89)\end{array}$ & $\begin{array}{l}\text { 11-year-old girls } \\
\text { (six lean, six over- } \\
\text { weight) }\end{array}$ & $\begin{array}{l}\text { Morning and afternoon } \\
\text { cycling exercise ( } 1.5 \mathrm{MJ} \\
\text { energy expenditure) was } \\
\text { subsequently imposed on } \\
2 \text { consecutive days as part } \\
\text { of the 5-day intervention. }\end{array}$ & $\begin{array}{l}\text { No exercise-induced diffe- } \\
\text { rences in total daily or } 5 \text {-day } \\
\text { total energy intake were } \\
\text { observed between groups or } \\
\text { treatments }\end{array}$ & $\begin{array}{l}\text { Overweight girls, } \\
\text { rated their appetite } \\
\text { immediately after } \\
\text { exercise as being } \\
\text { stronger than they } \\
\text { rated it before } \\
\text { exercise }\end{array}$ \\
\hline $\begin{array}{l}\text { Broom, et al. } \\
(90)\end{array}$ & $\begin{array}{l}\text { Normal weight } \\
\text { male students }\end{array}$ & $\begin{array}{l}\text { Resistance exercise: a } \\
90 \text {-min free weight lifting } \\
\text { session followed by a } 6.5 \text {-h } \\
\text { rest period and aerobic } \\
\text { exercise: a } 60 \text {-min run fol- } \\
\text { lowed by a } 7 \text {-h rest period } \\
\text { versus resting }\end{array}$ & Not tested & $\begin{array}{l}\text { Suppressed hunger } \\
\text { during aerobic and } \\
\text { resistance exercise }\end{array}$ \\
\hline $\begin{array}{l}\text { Cheng et al. } \\
\text { (91) }\end{array}$ & $\begin{array}{l}\text { Moderately active } \\
\text { normal weight } \\
\text { young men }\end{array}$ & $\begin{array}{l}\text { Exercise at } 60 \% \text { of VO- } \\
2 \text { max for } 50 \text { min per- } \\
\text { formed three trials in a } \\
\text { random exercise } 2 \mathrm{~h} \text { after } \\
\text { or } 1 \mathrm{~h} \text { before a meal. }\end{array}$ & Not tested & $\begin{array}{l}\text { Exercise per- } \\
\text { formed } 2 \mathrm{~h} \text { after } \\
\text { meal extended the } \\
\text { appetite suppres- } \\
\text { sing effect of food } \\
\text { intake. Exercise } \\
\text { prior to food intake } \\
\text { decreased appetite }\end{array}$ \\
\hline
\end{tabular}




\section{Effect of exercise on plasma levels of appetite-related hormones}

Effect of exercise on release of hormones engaged in food intake regulation is a subject that has obtained a lot of consideration lately, with a special attention on leptin and ghrelin. It seems that circulating leptin levels are only decreased by exercise with high intensity and long duration and in the absence of weight loss no significant change in the fasting plasma levels of this hormone is observed (92-98). In one study, however marked and significant decrease in plasma leptin was observed in marathon swimmers after 25 $\mathrm{km}$ swimming race (99) even after adjusting for BMI and fat mass. This effect could be explained by a fact that subjects were not in a fasting state, therefore allowing the release of insulin, which is known to exert a negative feedback over leptin secretion (100). Extreme exercise in healthy normal weight men was reported to significantly increase plasma leptin concentrations and authors suggested that origin of this increment was rather from stomach rather than from the adipose tissues (101). A number of studies have investigated the effects of training on leptin concentrations. These studies have reported either no effect of training on leptin concentrations with short-term training $(<12$ weeks), or a reduction in leptin levels in long-term training (>12 weeks) studies. The reduction of leptin has been attributed to alteration in energy balance, improvements in insulin sensitivity and alteration in lipid metabolism and lipid concentration (102). Some authors have shown that circulating leptin levels in athletes are lower than in sedentary subjects, maybe because of the lower body fat content of the sportsmen and probably as a result of the complex neurohormonal adaptations on the long-term physical training (103).

Ghrelin is a potent GH secretagogue and exercise is a potent stimulus of $\mathrm{GH}$ secretion; thus, ghrelin could affect GH responses to exercise and recovery or GH could alter ghrelin levels via negative feedback $(25,102)$. Although acute exercise, has been shown without effect on fasting plasma levels of ghrelin, in either normal weight (97) or overweight volunteers, (104) the results may be dependent on the intensity of exercise, with low- rather than high-intensity exercise stimulating total plasma ghrelin levels independently of its duration (88). There is some evidence that ghrelin levels are suppressed following resistance exercise of moderate intensity and are lower with higher $\mathrm{GH}$ concentrations during aerobic exercise. It has been suggested that negative feedback from elevated GH produces the reductions. Longterm chronic exercise produces increases in ghrelin levels, especially when weight loss is produced in overweight patients. In rats exercise caused increases in ghrelin concentrations. In one of a few studies which used acylated form of ghrelin (AG), one which exhibits orexigenic properties described a significant suppression in AG after the exercise, as well as a reduction in subjective hunger (105). Mackelvie et al (106) measured the effect of 5 days of aerobic exercise on total ghrelin, AG and desacyl ghrelin (DG) plasma levels in fasted state and postprandially, in normal weight and obese adolescent boys. They observed no change in total ghrelin plasma levels, but a significant increase in AG, independent of changes in body weight. The increase in AG was higher in the normal weight group and was associated with an increase in self-reported hunger measures and a decrease in fullness after a meal. Exercise was also associated with a decrease in postprandial DG in normal weight, but with an increase in overweight adolescents (106). Kim and colleagues examined the effect of a 12-week exercise program on total ghrelin, AG and DG in overweight children. They found no change in AG plasma levels but a significant increase in total and DG plasma levels and the decrease in bodyweight and body fat was strongly associated with the rise in DG plasma levels (107). In recent study on previously sedentary overweight man and women post exercise increase in ghrelin concentration with accompanying lack of appetite inhibition has been shown in women but not men (108).

Limited data suggests that adiponectin concentration presents a delayed increase ( $30 \mathrm{~min}$ ) after short-term intense exercise ( $<60 \mathrm{~min}$ ) performed by trained athletes (109-111). A sub-maximal aerobic exercise (65\% of $\mathrm{V}_{2}$ max) did not result in significant changes in adiponectin up to $48 \mathrm{~h}$ post-exercise in overweight subjects (112). It seems that, adiponectin concentrations do not change in response to long-term exercise ( $\geq 60 \mathrm{~min}$ ). Most training studies which improved fitness levels and affected body composition increased adiponectin concentrations $(113,114)$. FrydelundLarsen and colleagues examined visfatin mRNA expression in abdominal subcutaneous adipose tissue and skeletal muscle biopsies obtained from healthy young men after 3 $\mathrm{h}$ of ergometer cycle exercise at $60 \%$ of $\mathrm{V}_{2}$ max. Adipose tissue but not skeletal muscle visfatin mRNA expression increased threefold in response to exercise. This increase in adipose tissue visfatin was, however, not accompanied by elevated levels of plasma visfatin (115). Exercise training with weight loss induced a significant reduction of plasma visfatin and eotaxin levels in non-diabetic Korean women (116). In recent study Jurimae et al. (117) measured plasma visfatin and ghrelin responses to a single endurance rowing training session in male competitive single scull rowers. Plasma visfatin was reduced, and ghrelin concentration was increased after a 30 -min post exercise.

Relatively few studies examined the effects of exercise on the plasma levels of other hormones involved in appetite regulation. Acute exercise was found to increase fasting and postprandial levels of polypeptide YY, CCK, GLP-1 and PP $(67,101)$. A recently published research study investigated the effects of $60 \mathrm{~min}$ resistance and aerobic exercise on hunger and circulating levels of the gut hormones acylated ghrelin and peptide YY. Aerobic exercises proved to be effective in the 
decreasing of the ghrelin levels, while increasing the amount of peptide YY. On the other hand resistance exercise increased ghrelin levels but did not did not elevate post-exercise PYY levels in the study (90). Ueda et al. examined whether changes in gut hormone levels due to a single bout of aerobic exercise differ between obese young males and normal controls, and attempted to determine the involvement of hormonal changes during exercise in the regulation of energy balance in these obese subjects. Plasma levels of PYY and GLP1 were increased by exercise, whereas plasma ghrelin levels were unaffected by exercise and there was no significant difference between the two groups (118).

In recent study (91) researchers wanted to assess how the timing of that meal would impact the effect of exercise (60\% $\mathrm{VO}_{2}$ max for 50 minutes) on the appetite and some of its mediators - ghrelin, leptin and PYY ${ }_{3-36}$. The study found that when exercise was performed 2 hours after meal consumption extended the appetite suppressing effect of food intake. Furthermore, plasma PYY (3-36) concentration tended to be elevated by exercise after meal consumption. Exercise prior to food intake decreased appetite and increased plasma ghrelin concentrations. No response to timing of exercise relative to food intake on plasma leptin concentration was detected. Authors concluded that the timing of exercise to meal consumption may influence appetite and its hormonal regulators and post-meal exercise may extend the suppressive effects of meal consumption on appetite (91).

Table 2. Studies assessing the effect of exercise on peptides involved in food intake control

\begin{tabular}{|c|c|c|c|}
\hline Reference & Subjects & Intervention & Outcome \\
\hline Hilsted et al.(119) & Marathon runners (male) & $\begin{array}{l}\text { 3h of exercise (cycle er- } \\
\text { gometer) at } 40 \% \dot{\mathrm{VO}}_{2} \max \\
\text { versus resting }\end{array}$ & $\begin{array}{l}\text { Significant increase in } \\
\text { fasting PP levels }\end{array}$ \\
\hline Greenberg et al. (120) & $\begin{array}{l}\text { Normal-weight volunteers } \\
\text { (males and females) }\end{array}$ & $\begin{array}{l}45 \text { min of exercise (cycle } \\
\text { ergometer) at } 50 \% \dot{\mathrm{VO}}_{2} \max \text {, } \\
30 \text { min after breakfast versus } \\
\text { resting }\end{array}$ & $\begin{array}{l}\text { Significant increase in } \\
\text { postprandial plasma levels } \\
\text { of PP }\end{array}$ \\
\hline Hurley et al.(121) & $\begin{array}{l}\text { Normal weight sedentary } \\
\text { men }\end{array}$ & $\begin{array}{l}10 \text { weeks exercise program- } \\
\text { me }(20 \text { min of jogging at } \\
70 \% \dot{\mathrm{VO}}_{2} \max \text {, three times/ } \\
\text { week })\end{array}$ & $\begin{array}{l}\text { Slight increase in PP fasting } \\
\text { and postprandial plasma } \\
\text { levels }\end{array}$ \\
\hline O’Connor et al.(122) & $\begin{array}{l}\text { Marathon runners (males } \\
\text { and females) }\end{array}$ & Marathon running & $\begin{array}{l}\text { Significant increases in fa- } \\
\text { sting GLP-1 and PP plasma } \\
\text { levels }\end{array}$ \\
\hline Bailey et al.(123) & $\begin{array}{l}\text { Physically active normal- } \\
\text { weight men }\end{array}$ & $\begin{array}{l}\text { Cycling test to exhaustion } \\
\text { versus resting } 4 \text {-week } \\
\text { cycling exercise programme } \\
\text { (three times/ week with } \\
\text { incremental duration and } \\
\text { intensity) }\end{array}$ & $\begin{array}{l}\text { Significant increase in fa- } \\
\text { sting CCK plasma levels }\end{array}$ \\
\hline Sliwowski et al.(101) & Normal-weight men & $\begin{array}{l}\text { Treadmill run to exhaustion } \\
\text { in fasting or fed state ( } 5 \text { min } \\
\text { after a liquid meal) }\end{array}$ & $\begin{array}{l}\text { Significant increase in CCK } \\
\text { and PP plasma levels after } \\
\text { exercise, independently of } \\
\text { feeding. Fall in leptin level } \\
\text { after meal }\end{array}$ \\
\hline Dall et al. (124) & $\begin{array}{l}\text { Healthy and growth hormo- } \\
\text { ne-deficient men }\end{array}$ & $\begin{array}{l}\text { Submaximal aerobic exerci- } \\
\text { se on a cycle ergometer for } \\
45 \text { min versus resting }\end{array}$ & $\begin{array}{l}\text { No significant change in } \\
\text { ghrelin plasma level }\end{array}$ \\
\hline Ferguson et al.(114) & $\begin{array}{l}\text { Normal-weight male and } \\
\text { female subjects }\end{array}$ & $\begin{array}{l}60 \text {-minute exercise (cyc- } \\
\text { le ergometer) at } 65 \% \text { of } \\
\dot{\mathrm{V}}_{2} \text { max versus resting }\end{array}$ & $\begin{array}{l}\text { No significant changes in } \\
\text { adiponectin and leptin } \\
\text { plasma levels }\end{array}$ \\
\hline Kraemer et al. (125) & Normal-weight men & $\begin{array}{l}\text { Concentric and eccentric } \\
\text { muscle actions at the same } \\
\text { absolute workload }\end{array}$ & $\begin{array}{l}\text { No significant change in } \\
\text { ghrelin plasma level }\end{array}$ \\
\hline Zoladz et al. (97) & $\begin{array}{l}\text { Normal-weight non-smo- } \\
\text { king men }\end{array}$ & $\begin{array}{l}\text { Incremental exercise test, } \\
\text { with the increase of power } \\
\text { output by } 30 \mathrm{~W} \text { every } 3 \\
\text { minutes. }\end{array}$ & $\begin{array}{l}\text { No significant effect on } \\
\text { plasma ghrelin and leptin } \\
\text { levels }\end{array}$ \\
\hline Jamurtas et al.(126) & Healthy overweight males & $\begin{array}{l}\text { Exercise bout at about } 65 \% \\
\text { of } \dot{\mathrm{V}}_{2} \max \max \end{array}$ & $\begin{array}{l}\text { No significant changes in } \\
\text { adiponectin plasma levels }\end{array}$ \\
\hline
\end{tabular}




\begin{tabular}{|c|c|c|c|}
\hline Reference & Subjects & Intervention & Outcome \\
\hline Jurimae et al.(109) & College level rowers & $\begin{array}{l}\text { Rowing over a distance of } \\
6.5 \mathrm{~km} \text { at the individual } \\
\text { anaerobic threshold. }\end{array}$ & $\begin{array}{l}\text { Adiponectin and leptin } \\
\text { were unchanged imme- } \\
\text { diately after the exercise. } \\
\text { Adiponectin was signifi- } \\
\text { cantly increased and leptin } \\
\text { decreased after } 30 \text { min of } \\
\text { recovery }\end{array}$ \\
\hline \multirow[t]{2}{*}{ O'Connor et al.(127) } & $\begin{array}{l}\text { Endurance-trained male } \\
\text { athletes }\end{array}$ & $\begin{array}{l}\text { 2-h treadmill running at } \\
60 \% \dot{\mathrm{VO}}_{2} \text { max versus resting }\end{array}$ & \\
\hline & $\begin{array}{l}\text { Significant increases in } \\
\text { fasting GLP-1 }\end{array}$ & & \\
\hline Burns et al.(128) & $\begin{array}{l}\text { Normal weight men and } \\
\text { woman }\end{array}$ & $\begin{array}{l}\text { 1-h treadmill run at } 73.5 \% \\
\text { of } \dot{\mathrm{V}} \mathrm{O}_{2} \text { max versus resting }\end{array}$ & $\begin{array}{l}\text { No significant change in } \\
\text { ghrelin plasma level }\end{array}$ \\
\hline Broom et al (129) & Normal weight men & $\begin{array}{l}\text { Running for } 60 \text { min at } 72 \% \\
\text { of maximum oxygen and } \\
\text { after } 8 \text { hrs rest test meal ver- } \\
\text { sus resting and test meal. }\end{array}$ & $\begin{array}{l}\text { Area under the curve } \\
\text { values for plasma acylated } \\
\text { ghrelin concentration was } \\
\text { lower compared with the } \\
\text { control trial. }\end{array}$ \\
\hline Erdmann et al. (88) & $\begin{array}{l}\text { Normal weight volunteers } \\
\text { (males and females) }\end{array}$ & $\begin{array}{l}\text { Group A cycling for } 30 \text { min } \\
\text { at } 50 \mathrm{~W} \text { and } 100 \text { and group } \\
\mathrm{B} \text { at } 50 \mathrm{~W} \text { for } 30,60 \text { and } 120 \\
\text { min versus resting }\end{array}$ & $\begin{array}{l}\text { Ghrelin concentrations } \\
\text { rose significantly at } 50 \mathrm{~W} \\
\text { but remained unchanged } \\
\text { during the higher intensity } \\
\text { at } 100 \mathrm{~W} \text {. }\end{array}$ \\
\hline Jurimae et al.(130) & Highly trained male rowers & $\begin{array}{l}\text { Single scull rowing was } \\
\text { performed below and above } \\
\text { individual anaerobic thre- } \\
\text { shold }\end{array}$ & $\begin{array}{l}\text { No significant effect in } \\
\text { plasma ghrelin and leptin } \\
\text { levels }\end{array}$ \\
\hline Jurimae et al.(131) & Elite male rowers & $\begin{array}{l}\text { Maximal 6000-m rowing } \\
\text { ergometer test }\end{array}$ & $\begin{array}{l}\text { Ghrelin was significantly } \\
\text { increased and leptin signifi- } \\
\text { cantly decreased imme- } \\
\text { diately after the exercise } \\
\text { and remained significantly } \\
\text { decreased after the first } 30 \\
\text { mins of recovery. }\end{array}$ \\
\hline Chanoine, et al. (132) & $\begin{array}{l}\text { Normal-weight and overwe- } \\
\text { ight male adolescents }\end{array}$ & $\begin{array}{l}5 \text { consecutive days of super- } \\
\text { vised aerobic exercise (1 } \\
\text { h/day) }\end{array}$ & $\begin{array}{l}\text { Significant increase in GLP- } \\
1 \text { response postprandially, } \\
\text { independently of weight }\end{array}$ \\
\hline Martins et al. (67) & $\begin{array}{l}\text { Normal weight sedentary } \\
\text { men and woman }\end{array}$ & $\begin{array}{l}1 \mathrm{~h} \text { or intermittent cycling } \\
\text { at } 65 \% \text { of max heart rate } \\
(1 \mathrm{~h} \text { after breakfast) versus } \\
\text { resting }\end{array}$ & $\begin{array}{l}\text { Significant increase in } \\
\text { postprandial levels of PYY, } \\
\text { GLP-1 and PP. No signifi- } \\
\text { cant effect of exercise } \\
\text { on postprandial levels of } \\
\text { ghrelin }\end{array}$ \\
\hline Mackelvie et al. (106) & $\begin{array}{l}\text { Normal-weight and over- } \\
\text { weight male adolescents }\end{array}$ & $\begin{array}{l}\text { One hour after a standardi- } \\
\text { zed breakfast, subjects either } \\
\text { cycled for } 60 \text { min at } 65 \% \text { of } \\
\text { their maximal heart rate or } \\
\text { rested }\end{array}$ & $\begin{array}{l}\text { Exercise significantly in- } \\
\text { creased PYY, GLP-1 and PP } \\
\text { levels. No significant effect } \\
\text { of exercise on postprandial } \\
\text { levels of ghrelin }\end{array}$ \\
\hline Kyriazis et al (133) & Young healthy obese males & $\begin{array}{l}\text { Single exercise session of } \\
\text { moderate intensity ( } 58.4 \text { of } \\
\dot{\mathrm{V}} \mathrm{O}_{2} \text { max) for } 60 \text { minutes }\end{array}$ & $\begin{array}{l}\text { No significant effect in } \\
\text { plasma ghrelin and leptin } \\
\text { levels }\end{array}$ \\
\hline Ghanbari-Niaki et al.(134) & Normal weight woman & $\begin{array}{l}\text { Circuit-resistance exercise } \\
(9 \text { exercises, } 25 \text { s per exerci- } \\
\text { se, at } 40,60 \text {, and } 80 \% \text { of one } \\
\text { repetition maximum.) }\end{array}$ & $\begin{array}{l}\text { No significant changes in } \\
\text { plasma obestatin }\end{array}$ \\
\hline Numao et al.(135) & Normal weight healthy men & $\begin{array}{l}60 \text {-min stationary cycle } \\
\text { exercise ( } 50 \% \text { peak oxygen } \\
\text { uptake) followed by } 30 \text {-min } \\
\text { rest versus resting }\end{array}$ & $\begin{array}{l}\text { Total adiponectin and high- } \\
\text { molecular-weight adipo- } \\
\text { nectin unchanged }\end{array}$ \\
\hline
\end{tabular}




\begin{tabular}{|c|c|c|c|}
\hline Reference & Subjects & Intervention & Outcome \\
\hline Broom et al. (90) & $\begin{array}{l}\text { Eleven healthy male stu- } \\
\text { dents }\end{array}$ & $\begin{array}{l}\text { Resistance exercise: a } \\
90 \text {-min free weight lifting } \\
\text { session followed by a } 6.5 \text {-h } \\
\text { rest period and aerobic exer- } \\
\text { cise: a } 60 \text {-min run followed } \\
\text { by a } 7 \text {-h rest period versus } \\
\text { resting }\end{array}$ & $\begin{array}{l}\text { Significantly decreased } \\
\text { ghrelin during aerobic and } \\
\text { resistance exercise and in- } \\
\text { creased PYY during aerobic } \\
\text { exercise }\end{array}$ \\
\hline Jurimae et al.(117) & Highly trained male rowers & $\begin{array}{l}\text { Rowing training session } \\
\text { about } 2 \text { h versus resting }\end{array}$ & $\begin{array}{l}\text { Plasma visfatin and leptin } \\
\text { were reduced, and ghrelin } \\
\text { concentration was in- } \\
\text { creased after a } 30 \text {-min } \\
\text { postexercise }\end{array}$ \\
\hline Ueda et al. (118) & $\begin{array}{l}\text { Obese young males and } \\
\text { normal weight controls }\end{array}$ & $\begin{array}{l}\text { A standardized breakfast } \\
\text { followed by constant cycling } \\
\text { exercise at } 50 \% \dot{\mathrm{VO}}_{2} \max \\
\text { or rest for } 60 \text { min versus } \\
\text { resting }\end{array}$ & $\begin{array}{l}\text { Plasma levels of PYY and } \\
\text { GLP-1 were increased by } \\
\text { exercise, plasma ghrelin } \\
\text { levels were unaffected }\end{array}$ \\
\hline
\end{tabular}

Even less evidence is available concerning chronic exercise, one study didn't found any change in fasting cholecystokinin plasma levels in active men and the other reported a slight increase in both fasting and peak postprandial PP plasma levels, in previously sedentary men, after an exercise intervention $(67,102)$. There was no change in obestatin level after short exercise bout in women (134) but in rats moderate treadmill exercise was able to reduce fundus and small intestine obestatin concentrations (136).

Wang and colleagues studied the effects of short(40 min) and long-term (40 min, 5 days/week for 8 weeks) exercise on levels of appetite regulatory hormones in plasma and hypothalamus of obese rats. After short-term exercise, the plasma concentrations of ghrelin and obestatin were not changed, but NPY level was decreased. Ghrelin and obestatin in the hypothalamus decreased, and recovered 12 after 24 $\mathrm{h}$ and NPY increased and recovered after $24 \mathrm{~h}$. After long-term exercise these changes were different in plasma and hypothalamus (137).

\section{Conclusions}

An important role for physical activity in obesity prevention and in the long-term maintenance of weight loss has been consistently reported. There is a lot of evidence supporting an advantageous role of exercise on appetite regulation. Physical exercise or training can decrease adiposity and play an important role in energy expenditure and influence hormonal concentrations. Motivation to eat and food intake in response to acute exercise seem to be modulated by gender, body weight and eating behavior. In general, acute exercise has no effect on subsequent $\mathrm{El}$ in men, whereas in women an increase in EI is usually observed, either decreasing or abolishing the effects of exercise on EB. Normal weight women, unlike men, report an increased palatability of foods with exercise and do not experience the transient suppression of hunger observed immediately after exercise. The evidence to date emphasizes the need to increase physical exercise levels, particularly in the face of the high prevalence of obesity. More research is necessary to explain the mechanisms behind the post exercise adjustments in short-term appetite control, and their long-term consequences.

\section{References}

1. Stanley S, Wynne K, McGowan B, et al. Hormonal regulation of food intake. Physiol Rev 2005; 85(4):1131-58.

2. Caballero B. The global epidemic of obesity: an overview. Epidemiol Rev 2007; 29:1-5.

3. Rolls ET. Sensory processing in the brain related to the control of food intake. Proc Nutr Soc 2007; 66(1):96-112.

4. Blundell JE. Perspective on the central control of appetite. Obesity (Silver Spring) 2006; 14 Suppl 4:160S-3S.

5. Power ML, Schulkin J. Anticipatory physiological regulation in feeding biology: cephalic phase responses. Appetite 2008; 50(2-3): 194-206.

6. Chaudhri OB, Salem V, Murphy KG, et al. Gastrointestinal satiety signals. Annu Rev Physiol 2008; 70: 239-55.

7. Coll AP, Farooqi IS, O'Rahilly S. The hormonal control of food intake. Cell 2007; 129(2): 251-62.

8. Wilber JF. Neuropeptides, appetite regulation, and human obesity. JAMA 1991; 266(2): 257-9.

9. Hyman MA. Systems biology: the gut-brain-fat cell connection and obesity. Altern Ther Health Med 2006; 12(1):10-6.

10. Valassi E, Scacchi M, Cavagnini F. Neuroendocrine control of food intake. Nutr Metab Cardiovasc Dis 2008; 18(2):15868.

11. Berthoud HR, Earle T, Zheng H, et al. Food-related gastrointestinal signals activate caudal brainstem neurons expressing both NMDA and AMPA receptors. Brain Res 2001; 915(2):143-54.

12. Schwartz GJ. The role of gastrointestinal vagal afferents in the control of food intake: current prospects. Nutrition 2000; 16(10): 866-73.

13. Fulton S, Pissios P, Manchon RP, et al. Leptin regulation of the mesoaccumbens dopamine pathway. Neuron 2006; 51(6): 811-22.

14. Yeomans MR, Blundell JE, Leshem M. Palatability: response to nutritional need or need-free stimulation of appetite? $\mathrm{Br}$ J Nutr, 2004; 92 Suppl 1: S3-14. 
15. Yeomans MR, Gray RW. Opioid peptides and the control of human ingestive behaviour. Neurosci Biobehav Rev 2002; 26(6): 713-28.

16. Gaetani S, Kaye WH, Cuomo V, et al. Role of endocannabinoids and their analogues in obesity and eating disorders. Eat Weight Disord 2008; 13(3): e42-e48

17. Viveros MP, de Fonseca FR, Bermudez-Silva FJ, et al. Critical role of the endocannabinoid system in the regulation of food intake and energy metabolism, with phylogenetic, developmental, and pathophysiological implications. Endocr Metab Immune Disord Drug Targets 2008; 8(3): 220-30.

18. Berggren JR, Hulver MW, Houmard JA. Fat as an endocrine organ: influence of exercise. J Appl Physiol 2005; 99(2):757-64.

19. Ronti T, Lupattelli G, Mannarino E. The endocrine function of adipose tissue: an update. Clin Endocrinol (Oxf) 2006; 64(4): 355-65.

20. Kadowaki T, Yamauchi T, Kubota N. The physiological and pathophysiological role of adiponectin and adiponectin receptors in the peripheral tissues and CNS. FEBS Lett 2008; 582(1): 74-80.

21. Cline MA, Nandar W, Prall BC, et al. Central visfatin causes orexigenic effects in chicks. Behav Brain Res 2008; 186(2): 293-7.

22. Pardini AW, Nguyen HT, Figlewicz DP, et al. Distribution of insulin receptor substrate-2 in brain areas involved in energy homeostasis. Brain Res 2006; 1112(1): 169-78.

23. Woods SC, Chavez M, Park CR, et al. The evaluation of insulin as a metabolic signal influencing behavior via the brain. Neurosci Biobehav Rev 1996; 20(1): 139-44.

24. Bjorbaek C, Kahn BB. Leptin signaling in the central nervous system and the periphery. Recent Prog Horm Res 2004; 59: 305-31.

25. Kojima M, Kangawa K. Structure and function of ghrelin. Results Probl Cell Differ 2008; 46:89-115.

26. Berthoud HR. Vagal and hormonal gut-brain communication: from satiation to satisfaction. Neurogastroenterol Motil 2008; 20 Suppl 1: 64-72.

27. Ren AJ, Guo ZF, Wang YK, et al. Obestatin, obesity and diabetes. Peptides 2009; 30(2):439-44.

28. Conlon JM. The origin and evolution of peptide YY (PYY) and pancreatic polypeptide (PP). Peptides 2002; 23:(2): 26978.

29. Karra E, Chandarana K, Batterham RL. The role of peptide YY in appetite regulation and obesity. J Physiol 2009; 587(Pt 1): $19-25$.

30. Holst JJ. The physiology of glucagon-like peptide 1. Physiol Rev 2007; 87(4): 1409-39.

31. Woods SC. Dietary synergies in appetite control: distal gastrointestinal tract. Obesity (Silver Spring) 2006; 14 Suppl $4: 171 \mathrm{~S}-8 \mathrm{~S}$.

32. Wynne K, Park AJ, Small CJ, et al. Subcutaneous oxyntomodulin reduces body weight in overweight and obese subjects: a double-blind, randomized, controlled trial. Diabetes 2005; 54(8): 2390-5.

33. Sandoval D. CNS GLP-1 regulation of peripheral glucose homeostasis. Physiol Behav 2008; 94(5): 670-4.

34. D'Alessio D. Intestinal hormones and regulation of satiety: the case for CCK, GLP-1, PYY, and Apo A-IV. JPEN J Parenter Enteral Nutr 2008; 32(5): 567-8.

35. Dhillo WS. Appetite regulation: an overview. Thyroid 2007; 17(5): 433-45.

36. King NA, Tremblay A, Blundell JE. Effects of exercise on appetite control: implications for energy balance. Med Sci Sports Exerc 1997; 29(8):1076-89.

37. King NA. What processes are involved in the appetite response to moderate increases in exercise-induced energy expenditure? Proc Nutr Soc, 1999; 58(1):107-13.

38. Westerterp-Plantenga MS, Verwegen CR, Ijedema MJ, et al. Acute effects of exercise or sauna on appetite in obese and nonobese men. Physiol Behav 1997; 62(6): 1345-54.

39. Blundell JE, King NA. Physical activity and regulation of food intake: current evidence. Med Sci Sports Exerc 1999; 31(11 Suppl): S573-83.
40. King NA, Lluch A, Stubbs RJ, et al. High dose exercise does not increase hunger or energy intake in free living males. Eur J Clin Nutr 1997; 51(7): 478-83.

41. King NA, Snell L, Smith RD, et al. Effects of short-term exercise on appetite responses in unrestrained females. Eur J Clin Nutr 1996; 50(10): 663-7.

42. King NA, Blundell JE. High-fat foods overcome the energy expenditure induced by high-intensity cycling or running. Eur J Clin Nutr 1995; 49(2): 114-23.

43. King NA, Burley VJ, Blundell JE. Exercise-induced suppression of appetite: effects on food intake and implications for energy balance. Eur J Clin Nutr 1994; 48(10): 715-24.

44. Blundell JE, King NA. Exercise, appetite control, and energy balance. Nutrition 2000; 16(7-8): 519-22.

45. Thompson DA, Wolfe LA, Eikelboom R. Acute effects of exercise intensity on appetite in young men. Med Sci Sports Exerc 1988; 20(3): 222-7.

46. Tremblay A, Therrien F. Physical activity and body functionality: implications for obesity prevention and treatment. Can J Physiol Pharmacol 2006; 84(2): 149-56.

47. Blundell JE, King NA. Effects of exercise on appetite control: loose coupling between energy expenditure and energy intake. Int J Obes Relat Metab Disord 1998; 22 Suppl 2: S22-9.

48. Hubert P, King NA, Blundell JE. Uncoupling the effects of energy expenditure and energy intake: appetite response to short-term energy deficit induced by meal omission and physical activity. Appetite 1998; 31(1): 9-19.

49. Ahrens RA, Bishop CL, Berdanier CD. Effect of age and dietary carbohydrate source on the responses of rats to forced exercise. J Nutr 1972; 102(2): 241-7.

50. Bi S, Scott KA, Hyun J, et al. Running wheel activity prevents hyperphagia and obesity in Otsuka Long-Evans Tokushima fatty rats: role of hypothalamic signaling. Endocrinology 2005; 146(4): 1676-85.

51. Bi S, Ladenheim EE, Schwartz GJ, et al. A role for NPY overexpression in the dorsomedial hypothalamus in hyperphagia and obesity of OLETF rats. Am J Physiol Regul Integr Comp Physiol 2001; 281(1): R254-60

52. Oscai LB, Holloszy JO. Effects of weight changes produced by exercise, food restriction, or overeating on body composition. J Clin Invest 1969; 48(11): 2124-8.

53. Richard D, Rivest $\mathrm{S}$. The role of exercise in thermogenesis and energy balance. Can J Physiol Pharmacol 1989; 67(4): 402-9.

54. Stevenson JA, Box BM, Feleki V, et al. Bouts of exercise and food intake in the rat. J Appl Physiol 1966; 21(1): 118-22.

55. Rivest $S$, Richard D. Involvement of corticotropin-releasing factor in the anorexia induced by exercise. Brain Res Bull 1990; 25(1): 169-72.

56. Gray TS. Amygdaloid CRF pathways. Role in autonomic, neuroendocrine, and behavioral responses to stress. Ann N Y Acad Sci 1993; 697: 53-60.

57. Bovetto S, Richard D. Lesion of central nucleus of amygdala promotes fat gain without preventing effect of exercise on energy balance. Am J Physiol 1995; 269(4 Pt 2): R781-6.

58. Rivest $S$, Richard D. Hypothalamic paraventricular nucleus lesions do not prevent anorectic effect of exercise in male rats. Am J Physiol 1990; 259(3 Pt 2): R579-84.

59. Lewis DE, Shellard L, Koeslag DG, et al. Intense exercise and food restriction cause similar hypothalamic neuropeptide $\mathrm{Y}$ increases in rats. Am J Physiol 1993; 264(2 Pt 1): E279-84.

60. Levitsky DA. Feeding patterns of rats in response to fasts and changes in environmental conditions. Physiol Behav 1970; 5(3): 291-300.

61. Looy H, Eikelboom R. Wheel running, food intake, and body weight in male rats. Physiol Behav 1989; 45(2): 403-5.

62. Kawaguchi M, Scott KA, Moran TH, et al. Dorsomedial hypothalamic corticotropin-releasing factor mediation of exercise-induced anorexia. Am J Physiol Regul Integr Comp Physiol 2005; 288(6): R1800-5.

63. Kissileff HR, Pi-Sunyer FX, Segal K, et al. Acute effects of exercise on food intake in obese and nonobese women. Am J Clin Nutr 1990; 52(2): 240-5. 
64. Saltin B. Exercise hyperaemia: magnitude and aspects on regulation in humans. J Physio 2007; 583(Pt 3): 819-23.

65. Rowell LB, Blackmon JR, Bruce RA. Indocyanine green clearance and estimated hepatic blood flow during mild to maximal exercise in upright man. J Clin Invest 1964; 43: 1677-90.

66. Clausen JP. Effect of physical training on cardiovascular adjustments to exercise in man. Physiol Rev 1977; 57(4): 779-815.

67. Martins C, Morgan LM, Bloom SR, et al. Effects of exercise on gut peptides, energy intake and appetite. J Endocrinol 2007; 193(2): 251-8.

68. Lim CL, Lee LK. The effects of 20 weeks basic military training program on body composition, $\mathrm{VO}_{2}$ max and aerobic fitness of obese recruits. J Sports Med Phys Fitness 1994; 134: 271-8.

69. Woo R, Garrow JS, Pi-Sunyer FX. Effect of exercise on spontaneous calorie intake in obesity. Am J Clin Nutr 1982; 36(3): 470-7.

70. Woo R, Garrow JS, Pi-Sunyer FX. Voluntary food intake during prolonged exercise in obese women. Am J Clin Nutr 1982; 36(3): 478-84.

71. Woo R, Pi-Sunyer FX. Effect of increased physical activity on voluntary intake in lean women. Metabolism 1985; 34(9): 836-41.

72. Imbeault $\mathrm{P}$, Saint-Pierre $\mathrm{S}$, Almeras $\mathrm{N}$, et al. Acute effects of exercise on energy intake and feeding behaviour. Br J Nutr 1997; 77(4): 511-21.

73. Hagobian TA, Sharoff CG, Stephens BR, et al. Effects of exercise on energy-regulating hormones and appetite in men and women. Am J Physiol Regul Integr Comp Physiol, 2009; 296(2):R233-42

74. Whybrow S, Hughes DA, Ritz P, et al. The effect of an incremental increase in exercise on appetite, eating behaviour and energy balance in lean men and women feeding ad libitum. Br J Nutr 2008; 100(5): 1109-15.

75. Davy BM, Van Walleghen EL, Orr JS. Sex differences in acute energy intake regulation. Appetite 2007; 49(1): 141-7.

76. Pomerleau M, Imbeault P, Parker T, et al. Effects of exercise intensity on food intake and appetite in women. Am J Clin Nutr 2004; 80(5): 1230-6.

77. Durrant ML, Royston JP, Wloch RT. Effect of exercise on energy intake and eating patterns in lean and obese humans. Physiol Behav 1982; 29(3): 449-54.

78. Borer KT, Wuorinen E, Burant C (2008): Loss of ExerciseAssociated Suppression of Hunger and Plasma Leptin in Obese but Not in Lean Women. 90th Annual Meeting of the Endocrine Society, San Francisco, CA, P3-200.

79. Brobeck JR. Food intake as a mechanism of temperature regulation. Yale J Biol Med 1948; 20(6): 545-52.

80. Skibicka KP, Grill HJ. Hindbrain leptin stimulation induces anorexia and hyperthermia mediated by hindbrain melanocortin receptors. Endocrinology 2008; (in press).

81. Bensimhon DR, Kraus WE, Donahue MP. Obesity and physical activity: a review. Am Heart J 2006; 151(3): 598-603.

82. Lee S, Kuk JL, Davidson LE, et al. Exercise without weight loss is an effective strategy for obesity reduction in obese individuals with and without Type 2 diabetes. J Appl Physiol 2005; 99(3): 1220-5.

83. Poehlman ET, Dvorak RV, DeNino WF, et al. Effects of resistance training and endurance training on insulin sensitivity in nonobese, young women: a controlled randomized trial. J Clin Endocrinol Metab 2000; 85(7): 2463-8.

84. Holt S, Brand J, Soveny C, et al. Relationship of satiety to postprandial glycaemic, insulin and cholecystokinin responses. Appetite 1992; 18(2): 129-41.

85. King NA, Appleton K, Rogers PJ, et al. Effects of sweetness and energy in drinks on food intake following exercise. Physiol Behav 1999; 66(2): 375-9.

86. Tremblay A, Despres JP, Bouchard C. The effects of exercisetraining on energy balance and adipose tissue morphology and metabolism. Sports Med 1985; 2(3): 223-33.

87. Lluch A, King NA, Blundell JE. Exercise in dietary restrained women: no effect on energy intake but change in hedonic ratings. Eur J Clin Nutr 1998; 52(4): 300-7.
88. Erdmann J, Tahbaz R, Lippl F, et al. Plasma ghrelin levels during exercise - effects of intensity and duration. Regul Pept 2007; 143(1-3): 127-35.

89. Dodd CJ, Welsman JR, Armstrong N. Energy intake and appetite following exercise in lean and overweight girls. Appetite 2008; 51(3): 482-8.

90. Broom DR, Batterham RL, King JA, et al. Influence of resistance and aerobic exercise on hunger, circulating levels of acylated ghrelin, and peptide YY in healthy males. Am J Physiol Regul Integr Comp Physiol 2009; 296(1): R29-R35

91. Cheng MH, Bushnell D, Cannon DT, et al. Appetite regulation via exercise prior or subsequent to high-fat meal consumption. Appetite 2009; 52(1): 193-8.

92. Landt M, Lawson GM, Helgeson JM, et al. Prolonged exercise decreases serum leptin concentrations. Metabolism 1997; 46(10): 1109-12.

93. Leal-Cerro A, Garcia-Luna PP, Astorga R, et al. Serum leptin levels in male marathon athletes before and after the marathon run. J Clin Endocrinol Metab, 1998; 83(7): 2376-9.

94. Duclos M, Corcuff JB, Ruffie A, et al. Rapid leptin decrease in immediate post-exercise recovery. Clin Endocrinol (Oxf) 1999; 50(3): 337-42.

95. Olive JL, Miller GD. Differential effects of maximal- and moderate-intensity runs on plasma leptin in healthy trained subjects. Nutrition 2001; 17(5): 365-9.

96. Zaccaria M, Ermolao A, Roi GS, et al. Leptin reduction after endurance races differing in duration and energy expenditure. Eur J Appl Physiol 2002; 87(2): 108-11.

97. Zoladz JA, Konturek SI, Duda K, et al. Effect of moderate incremental exercise, performed in fed and fasted state on cardio-respiratory variables and leptin and ghrelin concentrations in young healthy men. J Physiol Pharmacol 2005; 56(1): 63-85.

98. Zoladz JA, Duda K, Konturek SJ, et al. Effect of different muscle shortening velocities during prolonged incremental cycling exercise on the plasma growth hormone, insulin, glucose, glucagon, cortisol, leptin and lactate concentrations. J Physiol Pharmacol 2002; 53(3): 409-22.

99. Karamouzis I, Karamouzis M, Vrabas IS, et al. The effects of marathon swimming on serum leptin and plasma neuropeptide Y levels. Clin Chem Lab Med 2002; 40(2): 132-6.

100. Hickey MS, Calsbeek DJ. Plasma leptin and exercise: recent findings. Sports Med 2001; 31(8): 583-9.

101. Sliwowski Z, Lorens K, Konturek SJ, et al. Leptin, gastrointestinal and stress hormones in response to exercise in fasted or fed subjects and before or after blood donation. J Physiol Pharmacol 2001; 52(1): 53-70.

102. Martins C, Morgan L, Truby H. A review of the effects of exercise on appetite regulation: an obesity perspective. Int $\mathrm{J}$ Obes (Lond) 2008; 32(9): 1337-47.

103. Haluzikova D, Haluzik M, Nedvidkova J, et al. Effect of physical activity on serum leptin levels. Sb Lek 2000; 101(1): 89-92.

104. Borer KT, Wuorinen E, Chao C, et al. Exercise energy expenditure is not consciously detected due to oro-gastric, not metabolic, basis of hunger sensation. Appetite 2005; 45(2): 177-81.

105. Broom DR, Batterham RL, King JA, et al. Influence of resistance and aerobic exercise on hunger, circulating levels of acylated ghrelin, and peptide YY in healthy males. Am J Physiol Regul Integr Comp Physiol, 2009; 296(1):R29-R35.

106. Mackelvie KJ, Meneilly GS, Elahi D, et al. Regulation of appetite in lean and obese adolescents after exercise: role of acylated and desacyl ghrelin. J Clin Endocrinol Metab 2007; 92(2): 648-54.

107. Kim HJ, Lee S, Kim TW, et al. Effects of exercise-induced weight loss on acylated and unacylated ghrelin in overweight children. Clin Endocrinol (Oxf) 2008; 68(3): 416-22.

108. Hagobian TA, Sharoff CG, Stephens BR, et al. Effects of exercise on energy-regulating hormones and appetite in men and women. Am J Physiol Regul Integr Comp Physiol 2009; 296(2): R233-42.

109. Jurimae J, Hofmann P, Jurimae T, et al. Plasma adiponectin response to sculling exercise at individual anaerobic threshold in college level male rowers. Int J Sports Med 2006; 27(4): $272-7$ 
110. Jurimae J, Purge P, Jurimae T. Adiponectin and stress hormone responses to maximal sculling after volume-extended training season in elite rowers. Metabolism 2006; 55(1):13-9.

111. Jurimae J, Purge P, Jurimae T. Adiponectin is altered after maximal exercise in highly trained male rowers. Eur J Appl Physiol 2005; 93(4): 502-5.

112. Jamurtas AZ, Theocharis V, Koukoulis G, et al. The effects of acute exercise on serum adiponectin and resistin levels and their relation to insulin sensitivity in overweight males. Eur J Appl Physiol 2006; 97(1): 122-6.

113. Kraemer RR, Castracane VD. Exercise and humoral mediators of peripheral energy balance: ghrelin and adiponectin. Exp Biol Med (Maywood) 2007; 232(2): 184-94.

114. Ferguson MA, White LJ, McCoy S, et al. Plasma adiponectin response to acute exercise in healthy subjects. Eur J Appl Physiol 2004; 91(2-3): 324-9.

115. Frydelund-Larsen L, Akerstrom T, Nielsen S, et al. Visfatin mRNA expression in human subcutaneous adipose tissue is regulated by exercise. Am J Physiol Endocrinol Metab 2007; 292(1): E24-E31.

116. Choi KM, Kim JH, Cho GJ, et al. Effect of exercise training on plasma visfatin and eotaxin levels. Eur J Endocrinol 2007; 157(4): 437-42.

117. Jurimae J, Ramson R, Maestu J, et al. Plasma visfatin and ghrelin response to prolonged sculling in competitive male rowers. Med Sci Sports Exerc 2009; 41(1): 137-43.

118. Ueda SY, Yoshikawa T, Katsura Y, et al. Changes in gut hormone levels and negative energy balance during aerobic exercise in obese young males. J Endocrinol, 2009; 201(1):1519.

119. Hilsted J, Galbo H, Sonne B, et al. Gastroenteropancreatic hormonal changes during exercise. Am J Physiol 1980; 239(3): G136-40.

120. Greenberg GR, Marliss EB, and Zinman B. Effect of exercise on the pancreatic polypeptide response to food in man. Horm Metab Res 1986; 18(3):194-6.

121. Hurley RS, Bossetti BM, O'Dorisio TM, et al. The effect of exercise training on body weight and peptide hormone patterns in normal weight college-age men. J Sports Med Phys Fitness 1991; 31(1): 52-6.

122. O'Connor AM, Johnston CF, Buchanan KD, et al. Circulating gastrointestinal hormone changes in marathon running. Int J Sports Med 1995; 16(5): 283-7.

123. Bailey DM, Davies B, Castell LM, et al. Physical exercise and normobaric hypoxia: independent modulators of peripheral cholecystokinin metabolism in man. J Appl Physiol 2001; 90(1): 105-13

124. Dall R, Kanaley J, Hansen TK, et al. Plasma ghrelin levels during exercise in healthy subjects and in growth hormonedeficient patients. Eur J Endocrinol 2002; 147(1): 65-70.

125. Kraemer RR, Durand RJ, Hollander DB, et al. Ghrelin and other glucoregulatory hormone responses to eccentric and concentric muscle contractions. Endocrine, 2004; 24(1): 93-8.

126. Jamurtas AZ, Theocharis V, Koukoulis $G$, et al. The effects of acute exercise on serum adiponectin and resistin levels and their relation to insulin sensitivity in overweight males. Eur J Appl Physiol 2006; 97(1): 122-6.
127. O'Connor AM, Pola S, Ward BM, et al. The gastroenteroinsular response to glucose ingestion during postexercise recovery. Am J Physiol Endocrinol Metab 2006; 290(6): E1155-61.

128. Burns SF, Broom DR, Miyashita M, et al. A single session of treadmill running has no effect on plasma total ghrelin concentrations. J Sports Sci 2007; 25(6): 635-42.

129. Broom DR, Stensel DJ, Bishop NC, et al. Exercise-induced suppression of acylated ghrelin in humans. J Appl Physiol 2007; 102(6): 2165-71.

130. Jurimae J, Hofmann P, Jurimae T, et al. Plasma ghrelin responses to acute sculling exercises in elite male rowers. Eur J Appl Physiol 2007; 99(5): 467-74.

131. Jurimae J, Jurimae T, and Purge P. Plasma ghrelin is altered after maximal exercise in elite male rowers. Exp Biol Med (Maywood) 2007; 232(7): 904-9.

132. Chanoine JP, Mackelvie KJ, Barr SI, et al. GLP-1 and appetite responses to a meal in lean and overweight adolescents following exercise. Obesity (Silver Spring) 2008; 16(1): 202-4.

133. Kyriazis GA, Caplan JD, Lowndes J, et al. Moderate exerciseinduced energy expenditure does not alter leptin levels in sedentary obese men. Clin J Sport Med 2007; 17(1): 49-51.

134. Ghanbari-Niaki A, Saghebjoo M, Rahbarizadeh F, et al. A single circuit-resistance exercise has no effect on plasma obestatin levels in female college students. Peptides 2008; 29(3): 487-90.

135. Numao S, Suzuki M, Matsuo T, et al. Effects of acute aerobic exercise on high-molecular-weight adiponectin. Med Sci Sports Exerc 2008; 40(7): 1271-6.

136. Ghanbari-Niaki A, Jafari A, Abednazari H, et al. Treadmill exercise reduces obestatin concentrations in rat fundus and small intestine. Biochem Biophys Res Commun 2008; 372(4): 741-5.

137. Wang J, Chen C, Wang RY. Influence of short- and long-term treadmill exercises on levels of ghrelin, obestatin and NPY in plasma and brain extraction of obese rats. Endocrine 2008; 33(1): 77-83.

Received: January 29, 2009

Accepted: April 30, 2009

Published: May 5, 2009

Address for correspondence:

Jan Bilski

Department of Ergonomics and Exercise Physiology

Grzegorzecka 20

Jagiellonian University Medical College

31-531 Cracow, Poland

tel.: +48124219351

fax: +48124219351

e-mail: mpbilski@cyf-kr.edu.pl

Aneta Teległów: aneta.teleglow@awf.krakow.pl

Janina Zahradnik-Bilska: jbilska@gazeta.pl

Artur Dembiński: mpdembin@cyf-kr.edu.pl

Zygmunt Warzecha: mpwarzec@cyf-kr.edu.pl

\begin{tabular}{llll}
\hline Authors' contribution & B - Data Collection & D - Data Interpretation & F - Literature Search \\
A - Study Design & C - Statistical Analysis & E - Manuscript Preparation & G - Funds Collection
\end{tabular}

